\title{
Monitoring local inflammation in JIA
}

\author{
Johannes Roth \\ From 21st European Pediatric Rheumatology (PReS) Congress \\ Belgrade, Serbia. 17-21 September 2014
}

Juvenile idiopathic arthritis (JIA) is a chronic inflammatory disease which commonly shows a remitting-relapsing course. Monitoring disease activity and adaptation of immune-suppressive therapy is still a challenge in clinical practice. In previous work our group has shown that members of the S100-protein family are reliable biomarkers for monitoring arthritis in JIA patients on medication and that these proteins may even predict risk of relapses in these patients. In my talk I will present novel data regarding the local release mechanism of these proteins during joint inflammation, use of serum concentrations of these S100-proteins for monitoring JIA as well as novel molecular imaging methods based on local S100-protein expression in preclinical models of inflammation and arthritis.

\section{Disclosure of interest}

None declared.

Published: 17 September 2014

Submit your next manuscript to BioMed Central and take full advantage of:

- Convenient online submission

- Thorough peer review

- No space constraints or color figure charges

- Immediate publication on acceptance

- Inclusion in PubMed, CAS, Scopus and Google Scholar

- Research which is freely available for redistribution

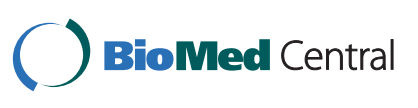

(c) 2014 Roth; licensee BioMed Central Ltd. This is an Open Access article distributed under the terms of the Creative Commons Attribution License (http://creativecommons.org/licenses/by/4.0), which permits unrestricted use, distribution, and reproduction in any medium, provided the original work is properly cited. The Creative Commons Public Domain Dedication waiver (http://creativecommons.org/publicdomain/zero/1.0/) applies to the data made available in this article, unless otherwise stated. 